\title{
"Not All Victims Matter": Belief in a Just World, Intergroup Relations and Victim Blaming
}

\author{
João Gabriel Modesto ${ }^{1}$ \\ Universidade Estadual de Goiás, Goianésia, GO, Brasil \\ Universidade de Brasília, Brasília, DF, Brasil \\ Ronaldo Pilati \\ Universidade de Brasília, Brasília, DF, Brasil
}

\begin{abstract}
The present research investigated the process of victim blaming in the context of intergroup relations through the just world hypothesis. In two studies we tested the influence of the victim's social category in the relationship between explicit and implicit beliefs in a just world (BJW) and victim blaming. In Study 1, 102 participants answered the explicit and implicit measures of BJW and evaluated how much a stray bullet victim (ingroup X outgroup) was to blame. In Study 2, aside from the manipulation of victim social category, we included a manipulation of cognitive load. 110 participants answered the BJW measures and evaluated how much a stray bullet victim (ingroup X outgroup) was to blame in a situation of cognitive load (low X high). It was verified that the victim's social category interferes in the relationship between BJW and victim blaming. When explicit or implicit BJW explained blaming, that effect was restricted to the evaluation of an ingroup victim. The findings of the present research confirm the hypothesis that ingroup victims are more threatening to individual's BJW and indicate the importance of considering the victim's social category for a more adequate understanding of the just world hypothesis.
\end{abstract}

Keywords: Belief in a just world, implicit processes, intergroup relations, cognitive load.

\section{“Nem todas as vítimas importam": Crenças no Mundo Justo, Relações Intergrupais e Responsabilização de Vítimas}

\section{Resumo}

A presente pesquisa investigou o processo de responsabilização de vítimas no contexto das relações intergrupais a partir da hipótese do mundo justo. Em dois estudos testamos a influência da categoria social da vítima na relação entre crenças no mundo justo (CMJ) explícita\implícita e a responsabilização de vítimas. No Estudo 1, 102 participantes responderam a medidas explícita e implícita da CMJ e avaliaram o grau de responsabilidade de uma vítima (endogrupo X exogrupo) de bala perdida. No Estudo 2, além da manipulação da categoria social da vítima, incluímos uma manipulação de carga cognitiva. Foram 110 participantes que responderam às medidas da $\mathrm{CMJ}$ e avaliaram a responsabilidade de uma vítima (endogrupo X exogrupo) de bala perdida em uma situação de carga cognitiva (baixa X alta). Verificouse que a categoria social da vítima interfere na relação da CMJ com a responsabilização. Quando a CMJ explícita ou implícita explicou a responsabilização, esse efeito foi restrito para a avaliação da vítima do

Mailing address: Universidade de Brasília, Campus Universitário Darcy Ribeiro, Instituto Central de Ciências, Instituto de Psicologia, Brasília, DF, Brazil 70.910-900. Phone: (71) 98767-8566. E-mail: jg.modesto@gmail.com

This research was supported by a Master's Scholarship from CAPES for the first author, as well as a research productivity grant and a grant from the Edital Universal (478285/2013-2) from CNPq for the second author 
endogrupo. Os achados da presente pesquisa corroboram a hipótese que vítimas do endogrupo são mais ameaçadoras para a CMJ dos indivíduos, indicando a importância de considerar a categoria social da vítima para um adequado entendimento da hipótese do mundo justo.

Palavras-chave: Crenças no mundo justo, processos implícitos, relações intergrupais, carga cognitiva.

\section{“Ni Todas las Victimas Importan": Creencia en el Mundo justo, Relaciones Intergrupales y Reponsabilizacion de Victimas}

\section{Resumen}

Esta investigación examino' el proceso de responsabilizacion de victimas en el contexto de las relaciones intergrupales a partir de la hipótesis del mundo justo. En dos estudios investigamos la influencia de la categoría social de la víctima en la relación entre creencias en el mundo justo (CMJ) explicita/ implícita y la responsabilizacion de victimas. En el Estudio 1, 102 participantes respondieron medidas explicita y implícita de CMJ y evaluaron el grado de responsabilidad de una víctima (endogrupo $\mathrm{X}$ exogrupo) de bala perdida. En el Estudio 2, además de la manipulación de categoría social de la víctima, incluimos una manipulación de carga cognitiva. 110 participantes respondieron las medidas de la CMJ y evaluaron la responsabilidad de una víctima (endogrupo $\mathrm{X}$ exogrupo) de bala perdida en una situación de carga cognitiva (baja $\mathrm{X}$ alta). Fue encontrado que la categoría social de la víctima interfiere en la relación de la CMJ con la responsabilizacion. Cuando la CMJ explícita o implícita explicó la responsabilizacion, este efecto fue restricto a la evaluación de la víctima del endogrupo. Los resultados de esta investigación confirman la hipótesis de que víctimas del endogrupo son más amenazantes para la CMJ de los individuos y indican la importancia de considerar la categoría social de la victima para una comprensión adecuada de la hipótesis del mundo justo.

Palabras clave: Creencias en el mundo justo, procesos implícitos, relaciones intergrupales, carga cognitiva.

Imagine two situations. In the first, a coworker is a victim of a stray bullet. In the other, the accident occurs with a stranger. Are the two situations evaluated in the same way? Was the victim responsible for the accident? What interferes in the evaluation process in a victimization situation? According to the just world hypothesis (Lerner, 1980), the extent to which people believe that the world is a just place helps to explain their reaction to victims. Considering that other studies have demonstrated the importance of the victim's social category for an adequate understanding of the just world hypothesis (Aguiar, Vala, Correia, \& Pereira, 2008; Correia et al., 2012; Correia, Alves, Morais, \& Ramos, 2015; Correia, Vala, \& Aguiar, 2007; Halabi, Statman, \& Dovidio, 2015), the present research aimed to investigate the moderating role of the victim's social category in the relation between the explicit and implicit dimensions of Belief in Just World (BJW), on the one hand, and victim blaming, on the other.

\section{Implicit and Explicit Dimensions of BJW and the Reaction to Victims}

According to BJW, people act as though the world is just and orderly by believing that people get what they deserve and deserve what they get (Lerner, 1980). Being confronted with innocent victims, therefore, threatens this sense of justice (Ramos, Correia, \& Alves, 2014). People then seek to correct this sense of injustice, in order to avoid cognitive dissonance and to maintain the belief that the world is a just place (Hafer \& Rubel, 2015). In this manner, innocent victims are often blamed as a way to maintain BJW (Lerner \& Simmons, 1966).

However, this process is not entirely conscious or accessible through introspection (Lerner, 2003), which has led to the understanding of the existence of both explicit and implicit dimensions of BJW (Lerner, 1998; Lerner \& Goldberg, 1999). In order to have a better understanding of the construct, direct (Dalbert, 1999; Gouveia, 
Pimentel, Coelho, Maynart, \& Mendonça, 2010; Modesto, Figueredo, Gama, Rodrigues, \& Pilati, 2017; Rubin \& Peplau, 1975) and indirect measures to assess BJW (Callan, Ferguson, \& Bindemann, 2013; Hafer, 2000; Murray, Spadafore, $\&$ McIntosh, 2005) have been used.

With regards to the indirect measures, previous literature refers to both situational and dispositional measures (Hafer, 2000; Modesto \& Pilati, 2015). The main indirect situational measure is an adapted Stroop test that permits identifying if a certain situation of victimization threatens BJW. The measure consists of the evaluation of two groups of words, one with terms related to justice (e.g. justice and just) and other with neutral words (e.g. telephone and wood). The words are presented as a subliminal priming in a dark screen followed by a mask (a group of 8 asterisks) to prevent the post-retinal effect. The task consists of identifying the color of the word, the dependent variable being the time for the accomplishment of the task. The author found that, in threatening situations for BJW, the latency for identifying the colors of the words related to justice is longer compared to when identifying the color of neutral words (Hafer, 2000).

Most recently, understanding BJW as a disposition, an Implicit Association Test (IAT) (Greenwald, Mcghee, \& Schwartz, 1998) to measure the implicit dimension of BJW was developed (Modesto \& Pilati, 2015). The IATBJW evaluates the implicit attitude toward notions related to the stabilitylunpredictability of the world, key concepts for the comprehension of the non-conscious dimension of the BJW (Modesto \& Pilati, 2015). The IAT differs from the indirect situational strategies, as it measures the BJW of the individual as a disposition, regardless of the situation of victimization evaluated.

\section{BJW and the Social Category of the Victims}

In spite of the evidence of the relation between BJW and victim blaming (Hafer \& Bègue, 2005 for a review), not all situations of victimization threaten BJW.
Different victims present different threats to the BJW of the individuals. An innocent victim, whose suffering is persistent, seems to be the most threatening type to the maintenance of the BJW (Correia \& Vala, 2003; Lerner \& Simmons, 1966). On the other hand, people are usually concerned with what happens in "their own world", so being confronted with victims from other contexts and groups seems to be less threatening (Lerner \& Miller, 1978). Studies have confirmed this hypothesis through indirect situational measures (Aguiar et al., 2008; Correia et al., 2007) as well as explicit measures (Correia et al., 2012).

Although an ingroup victim is more threatening to BJW, this does not imply greater blaming of the ingroup victim compared to outgroup victims, because of ingroup favoritism (Aguiar et al., 2008; Anderson, 1992; Correia et al., 2007; Kleinke \& Meyer, 1990). Being confronted with outgroup victims, especially stigmatized ones, seems to offer less risk to BJW, as a result of system justification (Jost \& Banaji, 1994; LimaNunes, Pereira, \& Correia, 2013).

\section{Study 1}

Despite the evidence of the importance of considering the victim's social category for an adequate understanding of the effect of the explicit and implicit BJW, it is necessary to highlight conceptual and methodological differences among such traditions of research.

In studies on the explicit BJW and intergroup relationships, a direct measure of the BJW is used, the victim's social category is manipulated, and then the effect caused by the BJW in the reaction to the victim is tested, taking into account the experimental manipulation (Correia et al., 2012). Such studies have indicated that the effect of the BJW tends to occur in the evaluation of ingroup but not outgroup members.

With regard to the studies on the implicit BJW in the context of intergroup relationships, the BJW has not been measured as a disposition but based on the evaluation of the threat to the BJW. Studies using the adapted Stroop test (Hafer, 2000) have indicated that the contact 
with ingroup victims is more threatening to the BJW (Correia et al., 2007) and, consequently, the effect of the BJW has been restricted to the evaluation of ingroup members (Aguiar et al., 2008).

Even though the influence of the victim's social category on the relation between BJW and reaction to victims had been tested by means of direct and indirect situational measures, we did not find studies in the literature that test such a relation when BJW is measured simultaneously by direct and indirect dispositional measures. The measuring of the explicit and implicit dimensions in the same study has the advantage of permitting a comparison of the effect of such variables in the explanation of the reaction to the victims. In light of these considerations, Study 1 aimed to test the moderating role of the victim's social category (ingroup $\mathrm{X}$ outgrup) in the relation between explicitlimplicit BJW and victim blaming. The hypothesis is that, although outgroup members are more blamed than those of the ingroup, the BJW will only exert a positive influence on victim blaming in the evaluation of ingroup members.

\section{Method}

\section{Participants}

One hundred and four undergraduate students took part in the study. Two of them were excluded because they did not fully answer the research questions. The age of the 102 participants ranged from 16 to $34(M=20.45 ; S D=$ 3.18 ) and $51.00 \%$ of them were male.

\section{Measures}

To measure explicit BJW, the Portuguese translated version of the Global Belief in a Just World Scale (GBJWS) was used (Gouveia et al., $2010 ; \alpha=.77)$. The items of the GBJWS vary from 1 (totally disagree) to 6 (totally agree), with higher values indicating higher levels of explicit BJW.

The implicit dimension of BJW was measured by the IAT for global dimension of the BJW (Modesto \& Pilati, 2015; $\alpha=.70$ ). The result of the IAT oscillates between -2 and +2 , with higher values representing higher levels of implicit BJW. The IAT was chosen as it is the only indirect dispositional measure for the BJW, as far as we have found in the literature.

Victim blaming was evaluated using three items ( is " $\mathrm{X}$ " responsible for the situation in which they are?; is " $\mathrm{X}$ " guilty for the situation in which they are?; could " $X$ " have avoided the event?), with each of these ranged on a scale of 1 (nothing $\backslash$ absolutely not) to 7 (totally completely), adapted from previous studies (Correia, 2003). Such items, when grouped together, demonstrated a satisfactory internal consistency $(\alpha=.80)$.

The scenario evaluated by the participants was presented as a news report, which described a case of a victim of a stray bullet who was in a serious health condition, and needed to undergo surgery. In this way, the characteristics of the victim that threaten BJW the most were presented: an innocent victim whose suffering persists (Correia \& Vala, 2003; Lerner \& Simmons, 1966). For the manipulation of the victim's social category, the victim was presented as an undergraduate student when in the ingroup condition, whereas, when in the outgroup condition, the victim was presented as a crack cocaine user.

In order to guarantee the categorization of the crack cocaine user as an outgroup member, at the end of the study there was an experimental manipulation check, in which the participant had to answer if they were psychoactive substance users and, if so, which substances they used. The participants who informed that they had used crack cocaine would be excluded from the sample.

\section{Procedure}

Students were approached on a university campus and were invited to voluntarily take part in the research. Initially, the participants answered the IAT and the explicit measure of BJW. They were, then, randomly assigned into ingroup and outgroup conditions for the evaluation of the scenario. They answered about the degree of blame attributed to the victim, to the manipulation check item and, finally, they 
reported sociodemographic data. After the conclusion of the study, the participants received a debriefing. All data collection was performed in the laboratory, in sessions with up to four participants. Each participant had to answer the instruments individually on the computer. The data collection was done through Inquisit 4.0 software.

The present research did not present any physical, moral or psychological risk to the participants, and was conducted complying with the ethical principles of research with humans postulated by APA. All participants accepted to participate voluntarily and the anonymity of the given information was guaranteed.

\section{Data Analysis}

All of the analyses were conducted with SPSS (Statistical Package for the Social Sciences) 18.0 software. For a comparison among the experimental conditions, analyses of variance (ANOVA) were performed. For the tests of the effect of the BJW in victim blaming, linear regressions were performed. The hypothesis of moderation was tested, in accordance with recommendations of the area (Hayes, 2013), using PROCESS.

\section{Results}

Only five participants informed using some type of illegal substance, none reported being a crack cocaine user. In this way, it was guaranteed that a crack cocaine user was seen as an outgroup member and, thus, that none of the participants needed to be excluded. The exclusion criterion for crack cocaine users and not for users of other drugs is justified by the fact that, in Brazil, crack cocaine users represent a stigmatized group, which is not necessarily the case for users of other drugs. Even so, the following analyses reported were, first, conducted excluding the participants who were drugs users, and similar results were found.

In order to test the direct effect of the experimental manipulation of the victim's social category on victim blaming, an ANOVA was conducted. It was verified that outgroup members $(M=2.73 ; S D=1.50)$ were blamed more than those of the ingroup $(M=1.89 ; S D=$ $1.21), F(1.100)=9.50, p=.003, \eta^{2} p=.09$.

The direct effect of BJW in victim blaming was tested through linear regressions. There were no significant results either for the explicit dimension, $\beta=.17, t(101)=1.73, p=.087$, or for the implicit dimension, $\beta=.13, t(101)=$ $1.28, p=.203$.

As for the test of moderation for the explicit BJW, although the interaction between BJW and the victim's social category was not significant, $\beta=.30, t(101)=1.56, p=.122$, which does not represent a moderation, it was verified that the BJW only predicts the victim blaming in the evaluation of an ingroup member, $\beta=$ $.52, t(101)=2.50, p=.014$. This effect is not significant when an outgroup member is evaluated, $\beta=.01, t(101)=.05, p=.963$. For the implicit dimension, no effect in the evaluation of the victim was found.

\section{Discussion}

Study 1 investigated the moderating role of the victim's social category in the relation between explicit and implicit BJW and victim blaming. The hypothesis stated that, even though outgroup members were more blamed, the BJW would only influence victim blaming in the evaluation of those of the ingroup. As expected, the outgroup member was more blamed than the ingroup member, confirming the finding of ingroup favoritism from previous studies on victim blaming (Aguiar et al., 2008; Anderson, 1992; Correia et al., 2007; Kleinke $\&$ Meyer, 1990). The attribution of responsibility to an outgroup victim, especially to members of stigmatized groups, represents a way of maintening the status quo (Jost \& Banaji, 1994; Lima-Nunes et al., 2013). Ultimately, such reasoning is consistent with the just world hypothesis, via the assumption that good things happen to good people and bad things happen to bad people (Lerner, 1998). In this way, stigmatized groups, such as crack cocaine users in Brazil, tend to be blamed more when compared to ingroup victims. 
With regards to the influence of the BJW, the hypothesis was partially corroborated. Although the result of the moderation was not statistically significant, the BJW only exerted an effect on victim blaming for ingroup victims, confirming the idea that people are concerned with what happens "in their own world" and that victims of other contexts and groups are not so threatening to the maintenance of the BJW (Lerner \& Miller, 1978). This result can be interpreted as a consequence of perceiving outgroup members as though they were out of the scope of justice (Lima-Nunes et al., 2013; Opotow, 1990). In this way, situations of injustice involving such groups do not tend to threaten BJW of the individuals.

Study 1 presented some limitations. The effect of BJW was limited to the explicit dimension, with no effect of the implicit dimension being found. It is possible that this result had been influenced by the scenario evaluated. A deliberative scenario was used, which the participants had to use wide cognitive resources to evaluate. In such situations, explicit measures have been found to be better predictors than implicit measures (Asendorpf, Banse, \& Mücke, 2002; Fleischhauer, Strobel, Enge, \& Strobel, 2013). These findings, in addition to the results of Study 1, point to the necessity of also testing the hypotheses in less deliberative scenarios.

\section{Study 2}

Considering the findings of Study 1 and the fact that explicit measures are often better predictors than implicit measures in deliberative scenarios, Study 2 aimed to test the moderating role of the victim's social category in the relation between BJW and victim blaming in two distinct scenarios: high and low cognitive load. Cognitive load can be defined as the restriction of cognitive resources to process a certain amount of information (Dijksterhuis \& Van Knippenberg, 1995). The manipulation of the cognitive load was proposed to create less deliberative scenarios. Other studies indicate that, in such situations, implicit measures have more predictive power than explicit measures (Fleischhauer et al., 2013).

Study 2, thus, has the following experimental design between subjects: 2 (victim's social category: ingroup and outgroup) X 2 (cognitive load: high and low). The hypotheses for Study 2 remain the same: outgroup members will be more blamed than those of the ingroup, however, there will only be a positive relation between the BJW and victim blaming in the ingroup condition. Additionally, it is presumed that, in a high cognitive load condition, the effect of implicit BJW will be more robust than that of explicit BJW, whereas, in a low cognitive load condition, the effect of explicit BJW will prevail when compared to that of implicit BJW.

\section{Method}

\section{Participants}

One hundred and fifteen undergraduate students participated in Study 2, but five of them were excluded since they did not complete the procedure. Among the 110 valid cases, 56.4\% were female and $43.6 \%$ were male, and their ages ranged from 18 to 55 years $(M=24.01 ; S D$ $=6.29$ ).

\section{Measures}

As in Study 1, the Portuguese translated version of The Global Belief in a Just World Scale (GBJWS) was used to measure explicit BJW $(\alpha=.85)$, while the IAT was used to measure implicit BJW $(\alpha=.58)$, and the same three items were used to evaluate victim blaming $(\alpha=.84)$.

The scenario for Study 2, as in Study 1, was presented as a news report, which reported a case of a victim of a stray bullet, who was in a serious health condition and needed to undergo surgery. However, to facilitate load manipulation, the scenario was extended and it was presented in 11 vignettes. For the establishment of cognitive load, the time for reading the scenario was limited. The participant, in the high cogni- 
tive load condition, had 7 seconds to read each vignette. For the low cognitive load condition, the time for reading was unlimited. This manipulation was based on previous studies (Van Knippenberg, Dijksterhuis, \& Vermeulen, 1999) and is built on the concept of cognitive load as a restriction of cognitive resources to process a certain amount of information (Dijksterhuis \& Van Knippenberg, 1995). Therefore, by restricting the time, the participants will be put in a situation of higher cognitive load than those in the unlimited time condition.

Among the 11 vignettes, the first four had the function of activating the victim's social category, as well as introducing them as an innocent victim whose suffering persists. The other vignettes presented more details about the episode (e.g. " $\mathrm{X}$ was with their partner before the event. ' $\mathrm{X}$ was with me just before the event. It is difficult to believe. We had arranged to meet when $[\mathrm{X}]$ went back from their friend's house. Now I can only wait" "). The number of words per vignette varied from 34 to 36 . However, fewer words (from 17 to 27 words) were used in the first four vignettes to better guarantee that the information about the victim's social category, their innocence and the seriousness of the situation were processed in a more deliberative way, even in a high load condition. This decision was made in order to increase the chance of a higher effectiveness of the experimental manipulation and of the activation of the victim's characteristics that are more threatening to the BJW. The decision concerning the number of vignettes, the time for reading them and the number of words per vignette were made based on previous studies (Van Knippenberg et al., 1999) and on the performance of pre-tests.

For the load manipulation check, the participant had to answer an item about the pressure caused by the restricted time provided for reading the news ("Did you feel under pressure because of the restricted time when reading the news?"), which ranged from 1 (entirely disagree) to 10 (entirely agree).

\section{Procedure}

As in Study 1, participants were undergraduate students approached on the University campus. Initially, they answered the IAT-BJW and the explicit measure. They, then, had to read the scenario, answer the load manipulation check, respond to the items concerning victim blaming, and report sociodemographic date. The data collection took place in the laboratory, in sessions with up to four participants. Each participant had to answer the instruments individually on a computer. The research was developed using Inquisit version 4.0 software. Study 2 followed the same ethical principles as described in Study 1.

\section{Data Analysis}

As in Study 1, the analyses were performed with SPSS 18.0. In this study, the comparison among groups was also drawn through ANOVA, the direct effects of BJW in victim blaming through linear regressions, and the test of moderation with PROCESS.

\section{Results}

Among the participants, eight reported using some sort of drug; none reported being a crack cocaine user. Therefore, it was guaranteed that the crack cocaine user category was considered as an outgroup. As in Study 1, the analyses were, first, conducted excluding user of other drugs and, again, similar results were found.

As for the load manipulation through ANOVA, it was verified that the participants in high load condition felt more under pressure because of time $(M=7.39 ; S D=2.60)$ than the participants in the low load condition $(M=5.04$; $S D=2.41), F(1.108)=24.29, p<.001, \eta^{2} p=$ .18 , which indicates that the time used created a cognitive load.

As in Study 1, outgroup members ( $M$ $=2.62 ; S D=1.50$ ) were blamed more than ingroup members $(M=1,80, S D=.87), F(1$. $108)=12.49, p=.001, \eta^{2} p=.10$. This effect was independent of the cognitive load, as can be seen in Figure 1. 


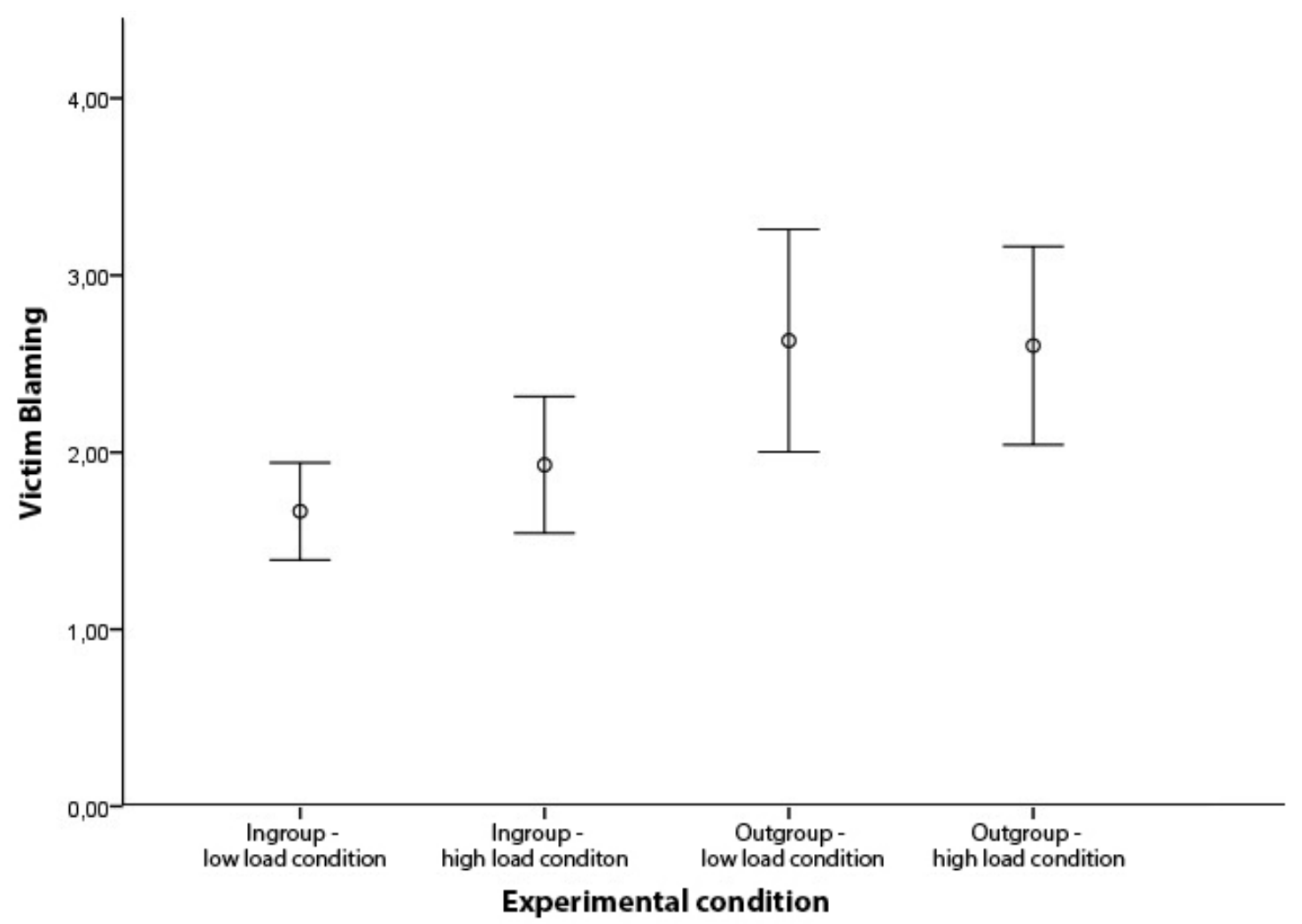

Error Bars: $95 \% \mathrm{Cl}$

Figure 1. Error bars diagram of the level of victim blaming per experimental condition.

Concerning the direct effect of the BJW, it was verified, through linear regressions, that the explicit BJW explained $6.5 \%$ of the blaming variance, $\beta=.26, t(109)=2.74, p=$ .007. Nevertheless, the implicit BJW did not significantly contributed to the direct explanation of victim blaming, $\beta=.10, t(109)=1.09, p=$ .279. The load manipulation did not influence victim blaming, $F(1,108)=.18, p=.67$.

When testing the moderating role of the victim's social category between the BJW and victim blaming, considering only the low load condition, an interaction between the explicit BJW and the social category was found $\beta=$ $.83, t(54)=3.68, p<.001$. The explicit BJW explains victim blaming only when ingroup members are evaluated, $\beta=.85, t(54)=$ $4.78, p<.001$, and the effect is not significant when outgroup members are evaluated, $\beta=$ $.03, t(54)=.19, p=.854$, which constitutes a moderation. When the high load condition is evaluated, an interaction effect is no longer found, $\beta=.13, t(53)=.47, p=.644$. In the high load condition, the explicit BJW did not exert any effect on the ingroup, $\beta=.30, t(53)=$ $1.41, p=.165$, or on the outgroup, $\beta=.17, t(53)$ $=1.01, p=.316$.

As for the implicit dimension of the BJW, in the low load condition, an interaction was not found, $\beta=.29, t(55)=1.18, p=.243$, thus, not representing a moderation. However, the implicit BJW explained the ingroup blaming, $\beta=$ $.39, t(55)=2.11, p=.040$, and the effect on the outgroup was not significant, $\beta=.10, t(55)=$ $.61, p=.547$. In the high load condition, no interaction effect was found, $\beta=.11, t(53)=.26, p=$ .797. For this condition, the implicit BJW did not influence the ingroup blaming, $\beta=.07, t$ (53) $=.39, p=.702$, or the outgroup blaming, $\beta=$ $.01, t(53)=.01, p=.991$.

\section{Discussion}

Study 2 tested the hypothesis of the moderating role of the victim's social category in the relation between the explicitlimplicit BJW and 
victim blaming in two distinct scenarios: low and high cognitive load.

As in Study 1, the hypothesis that the outgroup victims would be more blamed than ingroup victims was corroborated. The findings of Study 2 tend to reaffirm the understanding of ingroup favoritism found in other studies on victim blaming (Aguiar et al., 2008; Correia et al., 2012; Correia et al., 2007).

Concerning the explicit BJW, the hypothesis of the moderating role of the victim's social category on the explanation of victim blaming was corroborated. The explicit BJW only contributed to the explanation of victim blaming in the ingroup, confirming the idea that ingroup victims are more threatening to BJW than outgroup victims (Lerner \& Miller, 1978). The interaction effect between the explicit BJW and the victim's social category was only found in the more deliberative scenario in which the participants had more cognitive resources to evaluate it. In the high load situation (i.e. the less deliberative scenario), no direct effect of the explicit BJW was found, nor an interaction between the BJW and victim's social category. Considering that explicit measures tend to be more explanatorily powerful when the scenario evaluated permits the use of more cognitive resources (Asendorpf et al., 2002; Fleischhauer et al., 2013), it was expected that the explicit BJW effect would be limited to the scenario that was more deliberative.

For the implicit BJW, the hypothesis was partially corroborated. Although the test of moderation was not statically significant, the implicit BJW explained the ingroup victim blaming but not the outgroup case. This finding reaffirms the importance of considering the victim's social category in the investigation of the BJW, including when accessed through indirect measures (Aguiar et al., 2008; Correia et al., 2007).

However, the effect found for the implicit BJW was limited to the low cognitive load scenario, thereby differing from the hypothesis. It was expected that the cognitive load manipulation, by means of the restriction of the time for reading the scenario, would create a less deliberative scenario. This would facilitate the expression of the effect of the implicit BJW, and consequently its interaction with the victim's social category in the explanation of victim blaming. However, there was no effect in the high load condition, but there was in the low load condition. An alternative hypothesis is that, even though pre-tests were conducted, the time used to create load was very short and, as a result, the participants were not able to process the information of the scenario.

However, it is still important to determine what led to a significant result in the low load condition. There is evidence that stressful factors damage an individual's cognitive capacity (Klein \& Boals, 2001), for example, in situa-tions of threat (Schmader \& Johns, 2003). In such situations, the individuals tend to use their cognitive resources to suppress negative and undesirable thoughts and feelings, and, consequently, tend to concentrate less on the tasks that they are engaged in (Schmader \& Johns, 2003). Considering that situations of victimization threaten the $\mathrm{BJW}$, the scenario presented may have affected the participants' cognitive capacity, which led to a significant effect on the implicit BJW in the low load scenario. In Study 1, in a brief scenario, there was no effect of the implicit dimension. As for Study 2, in a scenario with more information, demanding more attention to process the information, the threat presentation itself may have caused the decrease of the cognitive resources available, which permitted an effect of the implicit dimension of the BJW.

\section{General Discussion}

The present research aimed to test the moderating role of the victim's social category in the relation between the explicitlimplicit BJW and victim blaming. Two studies in which the explicit and implicit BJW influenced the victim blaming were conducted and the effect was limited to the evaluation of ingroup members. The research findings corroborate the hypothesis that ingroup members are more threatening to BJW, and this, therefore, reaffirms the importance of considering the victim's social category for an 
adequate understanding of the hypothesis of a just world. This effect restricted to ingroup members can be interpreted by understanding that stigmatized groups can be perceived as out of the scope of justice (Lima-Nunes et al., 2013; Opotow, 1990). In this way, episodes of injustice involving such members do not threaten BJW.

We highlight that we did not find in the literature other studies that have tested the effect of the BJW on ingroup and outgroup victim blaming, when accessed simultaneously through directlindirect dispositional measures. Both Studies 1 and 2 permitted the comparison of the effect of the two dimensions of the BJW. It is recommended that new studies test the conditions under which each dimension exerts influence on victim blaming. It is necessary to clarify, for example, why the implicit dimension only presented an effect in the low load condition. In this research, we presented a post-hoc hypothesis that should be tested in other experiments for a better comprehension of the phenomenon.

\section{References}

Aguiar, P., Vala, J., Correia, I., \& Pereira, C. (2008). Justice in our world and in that of others: Belief in a Just World and reactions to victims. Social Justice Research, 21(1), 50-68. doi:10.1007/ s11211-007-0059-3

Anderson, V. N. (1992). For whom is this world just?: Sexual orientation and AIDS. Journal of Applied Social Psychology, 22(3), 248-259. doi:10.1111/j.1559-1816.1992.tb01538.x

Asendorpf, J. B., Banse, R., \& Mücke, D. (2002). Double dissociation between implicit and explicit personality self-concept: The case of shy behavior. Journal of Personality and Social Psychology, 83(2), 380-393. doi:10.1037//00223514.83.2.380

Callan, M. J., Ferguson, H. J., \& Bindemann, M. (2013). Eye movements to audiovisual scenes reveal expectations of a just world. Journal of Experimental Psychology. General, 142(1), 34 40. doi:10.1037/a0028261

Correia, I. (2003). Concertos e desconcertos na procura de um mundo concertado: Crença no Mundo Justo, inocência da vítima e vitimização secundária. Lisboa: Fundação Calouste Gulbenkian.
Correia, I., Alves, H., Morais, R., \& Ramos, M. (2015). The legitimation of wife abuse among women: The impact of belief in a just world and gender identification. Personality and Individual Differences, 76, 7-12. doi:10.1016/j. paid.2014.11.041

Correia, I., Alves, H., Sutton, R., Ramos, M., Gouveia-Pereira, M., \& Vala, J. (2012). When do people derogate or psychologically distance themselves from victims? Belief in a just world and ingroup identification. Personality and Individual Differences, 53(6), 747-752. doi:10.1016/j.paid.2012.05.032

Correia, I., \& Vala, J. (2003). Crença no mundo justo e vitimização secundária : O papel moderador da inocência da vítima e da persistência do sofrimento. Análise Psicológica, 3(XXI), 341-352. doi:10.14417/ap.15

Correia, I., Vala, J., \& Aguiar, P. (2007). Victim's innocence, social categorization, and the threat to the belief in a just world. Journal of Experimental Social Psychology, 43(1), 31-38. doi:10.1016/j.jesp.2005.12.010

Dalbert, C. (1999). The world is more just for me than generally: About the personal belief in a just world scale's validity. Social Justice Research, 12(2), 79-98. doi:10.1023/A:1022091609047

Dijksterhuis, A. P., \& Van Knippenberg, A. (1995). Timing of schema activation and memory: Inhibited access to inconsistent information. European Journal of Social Psychology, 25, 383-390. doi:10.1002/ejsp.2420250403

Fleischhauer, M., Strobel, A., Enge, S., \& Strobel, A. (2013). Assessing implicit cognitive motivation : Developing and testing an Implicit Association Test to measure Need for Cognition. European Journal of Personality, 29(1), 15-29. doi:10.1002/per.1841

Gouveia, V. V., Pimentel, C. E., Coelho, J. A. P. de M., Maynart, V. A. P., \& Mendonça, T. dos S. (2010). Validade fatorial confirmatória e consistência interna da Escala Global de Crenças no Mundo Justo - GJWS. Interação em Psicologia, 14(1), 21-29. doi:10.5380/psi.v14i1.12687

Greenwald, A. G., Mcghee, D. E., \& Schwartz, J. L. K. (1998). Measuring individual differences in implicit cognition: The Implicit Association Test. Journal of Personality and Social Psychology, 74(6), 1464-1480. doi:10.1037/00223514.74.6.1464 
Hafer, C. L. (2000). Do innocent victims threaten the belief in a just world? Evidence from a modified Stroop Task. Journal of Personality and Social Psychology, 79(2), 165-173. doi:10.1037/ AW22-3514.79.2.165

Hafer, C. L., \& Bègue, L. (2005). Experimental research on just-world theory: Problems, developments, and future challenges. Psychological Bulletin, 131(1), 128-167. doi:10.1037/0033-2909.131.1.128

Hafer, C. L. \& Rubel, A. N. (2015). The why and how of defending belief in a just world. In J. M. Olson \& M. P. Zanna (Eds.), Advances in Experimental Social Psychology (pp. 41-96). doi:10.1016/ bs.aesp.2014.09.001

Halabi, S., Statman, Y., \& Dovidio, J. F. (2015). Attributions of responsibility and punishment for ingroup and outgroup members: The role of just world beliefs. Group Processes \& Intergroup Relations, 18(1), 104-115. doi: $10.1177 / 1368430214546067$

Hayes, A. F. (2013). Introduction to mediation, moderation, and conditional process analysis: A regression-based approach. New York: The Guilford Press.

Jost, J. T., \& Banaji, M. R. (1994). The role of stereotyping in system-justification and the production of false consciousness. British Journal of Social Psychology, 33(1), 1-27. doi:10.1111/j.2044-8309.1994.tb01008.x

Klein, K., \& Boals, A. (2001). The relationship of life event stress and working memory capacity. Applied Cognitive Psychology, 15(5), 565-579. doi:10.1002/acp.727

Kleinke, C. L., \& Meyer, C. (1990). Evaluation of rape victim by men and women with high and low belief in a just world. Psychology of Women Quarterly, 14(3), 343-353. doi:10.1111/j.1471-6402.1990.tb00024.x

Lerner, M. J. (1980). The Belief in a Just World: A Fundamental Delusion. New York: Plennum Press.

Lerner, M. J. (1998). The two forms of belief in a just world: Some thoughts on why and how people care about justice. In L. Montada \& M. J. Lerner (Eds.), Responses to victimizations and belief in a just world (pp. 247-270). New York: Plenum Press.
Lerner, M. J. (2003). The Justice Motive: Where social psychologists found it, how they lost it, and why they may not find it again. Personality and Social Psychology Review, 7(4), 388-399. doi:10.1207/S15327957PSPR0704_10

Lerner, M. J., \& Goldberg, J. H. (1999). When do decent people blame victims? The differing effects of the explicit/rational and implicit/experiential cognitive systems. In S. Chaiken \& Y. Trope (Eds.), Dual process theories in social psychology (pp. 627-640). New York: Guilford.

Lerner, M. J., \& Miller, D. T. (1978). Just world research and the attribution process: Looking back and ahead. Psychological Bulletin, 85(5), 10301051. doi:10.1037//0033-2909.85.5.1030

Lerner, M. J., \& Simmons, C. H. (1966). The observer's reaction to the "innocent victim": Compassion or rejection? Journal of Personality and Social Psychology, 4(2), 203-210. doi:10.1037/ h0023562

Lima-Nunes, A., Pereira, C. R., \& Correia, I. (2013). Restricting the scope of justice to justify discrimination: The role played by justice perceptions in discrimination against immigrants. European Journal of Social Psychology, 43, 627-636. doi:10.1002/ejsp.1981

Modesto, J. G., Figueredo, V., Gama, G., Rodrigues, M., \& Pilati, R. (2017). Escala Pessoal de Crenças no Mundo Justo: Adaptação e evidências de validade. Psico-USF, 22(1), 13-22. doi: 10.1590/1413-82712017220102.

Modesto, J. G., \& Pilati, R. (2015). Implicit Deservingness: Implicit Association Test for Belief in a Just World. Interamerican Journal of Psychology, 49(2), 203-212.

Murray, J. D., Spadafore, J. A., \& McIntosh, W. D. (2005). Belief in a Just World and social perception: Evidence from automatic activation. The Journal of Social Psychology, 145(1), 35-47. doi:10.3200/SOCP.145.1.35-48

Opotow, S. (1990). Moral exclusion and injustice: An introduction. Journal of Social Issues, 46(1), 1-20. doi:10.1111/j.1540-4560.1990.tb00268.x

Ramos, M. R., Correia, I., \& Alves, H. (2014). To believe or not to believe in a just world? The psychological costs of threats to the belief in a just world and the role of attributions. Self and Identity, 13(3), 257-273. doi:10.1080/15298868 .2013 .798890 
Rubin, Z., \& Peplau, L. A. (1975). Who believes in a just world? Journal of Social Issues, 31(3), 6589. doi:10.1111/j.1540-4560.1975.tb00997.x

Schmader, T., \& Johns, M. (2003). Converging evidence that stereotype threat reduces working memory capacity. Journal of Personality and Social Psychology, 85(3), 440-52. doi:10.1037/0022-3514.85.3.440

Testé, B., \& Perrin, S. (2013). The impact of endorsing the belief in a just world on social judgments: The social utility and social desirability of Just-World Beliefs for self and others. Social Psychology, 44(3), 209-218. doi:10.1027/18649335/a000105
Van Knippenberg, A., Dijksterhuis, A., \& Vermeulen, D. (1999). Judgement and memory of a criminal act: The effects of stereotypes and cognitive load. European Journal of Social Psychology, 29(2-3), 191-201. doi:10.1002/ (SICI)1099-0992(199903/05)29:2/3<191::AIDEJSP923>3.0.CO;2-O
Recebido: 22/12/2015

$1^{a}$ revisão: $25 / 04 / 2016$ Aceite final: 28/04/2016 